\title{
Food System Transformation and the Role of Gene Technology: An Ethical Analysis
}

\author{
Paul B. Thompson
}

F

ood is a commonplace element of everyone's daily experience, so familiar that the ethical dimensions of producing, processing, distributing, and consuming food may seem simple to the point of obviousness. Allowing populations or individuals to go hungry is universally regarded as a moral evil. The series of internationally endorsed declarations supporting individual rights to adequate food begins with the 1945 UN Charter and the 1948 Universal Declaration of Human Rights. International cooperation for ensuring sustenance was reaffirmed and sharpened through the 1966 International Covenant on Economic, Social and Cultural Rights, as well as the 1974 Universal Declaration on the Eradication of Hunger and Malnutrition and the 1996 Rome Declaration on Food Security. Goal number one of the 2000 Millennium Development Goals calls for the eradication of hunger. Yet throughout this history, agencies charged with eradicating hunger have recognized complexities, ironies, and unintended consequences issuing from measures taken to achieve that objective.

Even a brief summary of the foibles encountered in efforts to alleviate or end global hunger would require considerably more discussion than the present context affords. Early efforts emphasized getting food from exporting nations into the mouths of hungry people. Programs to transfer technology from relatively more industrialized agricultural economies (especially the United States) to the agricultural sector of nations emerging from the shadow of colonialism came about in the

Ethics \& International Affairs, 35, no. 1 (2021), pp. 35-49.

(c) The Author(s), 2021. Published by Cambridge University Press on behalf of the Carnegie Council for Ethics in International Affairs. This is an Open Access article, distributed under the terms of the Creative Commons Attribution licence (http://creativecommons.org/licenses/by/4.o/), which permits unrestricted re-use, distribution, and reproduction in any medium, provided the original work is properly cited.

doi:10.1017/So892679421000034 
1960s. Hailed as a "green revolution," these programs were rapidly subjected to waves of critique and modification, with recent strategies offering more in the way of institutional reforms intended to protect land tenure, the natural resource base, and access to credit, especially for women. From an ethics standpoint, the tension between farm producers and urban consumers lies at the heart of this history.

Stated succinctly, people who buy food (whether for themselves or others) want it to be cheap, but producers need to sell it at a price that supports their livelihood. Programs that donate food to hungry consumers undermine the goals of farmers who are depending on local consumers to buy what they produce. Programs to promote agricultural development have increased total food production, substantially decreasing the percentage of a household budget consumers need to spend on food. However, they have often done so by disenfranchising smallholders and landless laborers, who then join the ranks of the urban poor. ${ }^{1}$ This problem is not unique to so-called developing economies. Technological innovations in chemistry, genetics, and mechanization spawned a dramatic transformation of U.S. agriculture throughout the nineteenth and early twentieth centuries. In important respects, the ethical issues associated with the impact of technological innovations in farm production continue even within the United States to this day.

Genetically engineered crops began to appear in North American fields in 1996 and 1997, but the European response to these new varieties of corn, cotton, soybeans, and canola sparked a global controversy. European concerns spilled over into less industrialized regions of the world, expanding the global controversy over the ethical acceptability of agricultural biotechnology. New and potentially more precise methods for modifying plant and animal genes started to appear around 2010. Some argue that given the increase in scientific control over genetic changes, the next generation of biotechnologies should escape the concerns that have so far retarded the adoption of genetically engineered crops and livestock. Others argue that the old issues are new again. Here, I will argue that any ethical evaluation of gene technology for agriculture must be contextualized within the fundamental problem for food ethics that I have sketched above: Technical changes in agriculture can disenfranchise farmers, even as they lower the cost of food and bring its accessibility into 
the reach of the urban poor. We should see the debates over genetically engineered foods as a special instance of this basic tension, rather than understanding it as a problem that is peculiar to international relations or biotechnology.

\section{The Technology Treadmill}

Agricultural technologies typically reduce the per-unit cost of food production by economizing on farming inputs. A new seed variety may increase the crop yield per unit of land, but it almost certainly does so in relation to numerous other shifts in the farmer's system. It may need more water or fertilizer, and it may increase or decrease the labor needs (even if this is simply a change in the amount of time or effort a farmer spends tending the crop). The costs a farmer bears in adopting a new technology include these changes, as well as any price paid to get access to the technology. However, many innovations of the last two hundred years offer an attractive bargain. For instance, Cyrus McCormick (1809-1884) developed and improved a series of designs for mechanical-harvesting equipment that reduced the labor needs for wheat production substantially. Farmer adoption of this mechanical technology was initially based on the judgment that the benefits of reducing the amount of time spent and the expense of hired labor for harvesting more than offset what was, in the nineteenth century, a substantial cost for acquiring the machinery. ${ }^{2}$

Early adopters of this mechanical technology could plant more land with less labor, and as a result were able to have more wheat to sell at the end of the season. They achieved a boost in income. However, as more and more farmers adopt a technology, the total amount of wheat produced increases accordingly. If (as is generally the case) production increases faster than demand, wheat prices fall as a result, and the increase in a farmer's income gradually declines. Farmers are on a treadmill: they run harder (produce more) to have roughly the same income. Nevertheless, early adopters may still be better off, if only for savings they earned before prices fell. The ethically significant impact was felt by farmers who were slow to buy a mechanical reaper in the 1800 s. Their costs did not decline, but they found themselves trying to sell into a market where the price they received reflected the lower price brought on by the increased production of the early 
adopters. They were no longer in a position of being able to choose how they farmed. They had to either adopt the new technology (albeit with less initial benefit than early adopters) or their relatively high production costs would eventually bankrupt them. ${ }^{3}$

It may not be obvious at first glance why this a problem from an ethics perspective. In part, this is because while agricultural economists differ on various issues, the majority take a classically utilitarian approach to technological innovations. That is, although there are losers in the farm economy, there are also winners. What is more, the general drop in the price of wheat creates more winners in other parts of the food economy, and especially so for consumers who will, the story goes, pay less for bread. Although details in the economic analysis can become torturous, the general thrust is that the benefits distributed across the economy as a whole must certainly outweigh the costs to producers who are forced to leave farming as a result of bankruptcy. Any alternative view must explain why the interests of farmers supplant the interests of those who benefit from cheaper food. In less industrialized economies, this privilege might consist in responding to the relative poverty and powerlessness of the farmers most likely to be slow in adopting a new technology. In the industrialized agricultural economies of the twentieth century, the story stresses how technological innovations only increase the privileges of those who were already privileged to start with. The debate then continues with pro-technology advocates noting that it is the least privileged among food consumers who derive the most benefit from a decrease in the price of bread.

In summary, there are at least two ways in which the treadmill raises ethical issues. First, it exemplifies the classical tension between utilitarian and more egalitarian or pro-poor versions of rights theory. Some may not see an ethical issue here, but even they should realize that their perspective is the result of a particular philosophical outlook. Needless to say, this theory-level dispute is central to development theory. Second, if, as I do, one takes poverty, gender, ethnicity, and a history of exploitation due to colonialism, racism, and white supremacy to constitute an ethical problem, then the technological treadmill provides an illustration of the way that discriminatory patterns become embedded within the socioeconomic structure of society. Such patterns endure long 
after conscious or attitudinal forms of enmity or bias subside. We should at least question whether the reproduction of such structural injustices is consistent with the development ideal.

\section{Gene Technology before rDNA}

The technology treadmill results in farmers running harder and harder to stay in the same place, with a few falling off and exiting farming at every increase in the treadmill's speed. While the treadmill metaphor is a straightforward way to explain the effects of mechanization, when we turn to gene technologies the story is more subtle, even if the result is the same. A change in crop genetics can be brought about by selective breeding, genetic engineering, or farmers simply choosing to save seed from individual plants that they happen to like; all of these activities alter the underlying genetics of a crop. An increase in yield can theoretically produce an effect much like the one described for McCormick's reaper, but more typically, changes in crop genetics depend upon interaction with other factors to have an effect. For example, running a mechanical reaper through a field is only useful if all the plants in the field can be harvested in a single pass. This was fine for wheat, but in the nineteenth century many crops, from cotton to tomatoes, ripened or became ready for harvest in an irregular manner, requiring workers to be in the field several times, picking only the fruits or bolls that were ready in each instance. For such crops, plant breeders worked to develop varieties with greater uniformity, enabling the development of mechanical harvesters.

Cotton varieties that could be mechanically harvested became common in the 1930s. This led to a massive displacement of a predominantly black workforce throughout the American South, precipitating the Great Migration to Northern manufacturing centers. ${ }^{4}$ An ethical evaluation connects many factors. On the one hand, Southern blacks living in the 1930 s endured socioeconomic conditions that cannot even begin to be described as morally justifiable. Racial prejudice was institutionalized through Jim Crow, while efforts at reform or resistance were suppressed through lynching and other forms of terrorism. A technological innovation's displacement of farm labor might be justified if the form of labor is itself unjustifiable. On the other hand, Franklin D. Roosevelt's Department of Agriculture was actively undertaking policy changes that would have tilted the 
balance of power from white landowners to black sharecroppers. ${ }^{5}$ Mechanically harvestable cotton mooted these efforts, and landless blacks, whose skill in managing cotton production made them essential to the earlier forms of cotton culture, were deprived of any voice in how an unjust system would be reformed. A considerable body of social science research documents the operation of the treadmill phenomenon in tomato production. In the 196os, the University of California used public funds to develop tomato varieties that could be harvested by commercially developed equipment. The mechanical tomato harvester could not be operated efficiently on small acreage. Within five years after its introduction, the California tomato industry transitioned from over two hundred farms of varying acreage to less than a dozen large acreage producers. ${ }^{6}$ In addition, the transition ended employment opportunities for thousands of Mexican migrant laborers who had been working in California under the Bracero Program. ${ }^{7}$ Thus the mechanization of the tomato industry-only possible in conjunction with the university's program in crop breeding-led to a concentration in ownership and farm operation, conjoined with the elimination of work for a vulnerable population of workers from a persecuted minority group. ${ }^{8}$

Green Revolution varieties of wheat and rice are perhaps the most widely known cases of a genetic technology disrupting traditional production, but the systemic interaction of farm inputs was quite complex in this case. Traditional varieties of wheat and rice respond to fertilization by growing too quickly and falling over (known as "lodging"), especially in high winds or heavy rain. Farmers in Europe and North America had commercially developed varieties that were less susceptible to lodging, especially under temperate growing conditions. They adopted synthetic fertilizers well before World War II, when the cost of petroleum needed to produce them was low. Farmers in Mexico, India, and Southeast Asia were unable to take advantage of synthetic fertilizers, because varieties of wheat and rice that performed well in tropical conditions were highly subject to lodging. Norman Borlaug won a Nobel Peace Prize in 1970 for developing dwarf varieties of these crops that were suitable for use in Mexico, India, and Southeast Asia, and not susceptible to lodging. Borlaug's varieties were adopted quickly by well-off farmers from these regions, but they were useless to those farmers who did not have the wealth to purchase synthetic fertilizer. ${ }^{9}$ As in the cotton and tomato cases, this led to uneven adoption of Green Revolution varieties, with 
comparatively better off (though still poor by Western standards) farmers being the primary beneficiaries, even though Green Revolution seeds were themselves nonproprietary and distributed freely through a number of public and philanthropic initiatives. ${ }^{10}$ Synthetic fertilizers themselves also came to be viewed as potential polluters of surface water and as potent contributors to greenhouse gases. $^{11}$

In each of these three cases, it was selective breeding, not genetic engineering, that was crucial for the development of plant varieties, as well as for farmers' ability to use technologies such as pesticides or synthetic fertilizer. These mechanical and chemical inputs, in turn, precipitated transformations in agriculture that were ethically controversial. Yet the technological transformations also sparked an increase in production of the respective commodities, and a corresponding reduction in price. This economic phenomenon was especially significant in the case of Green Revolution crops, because increased production of wheat, rice, and, later, maize played a large role in reducing hunger among food consumers who were not themselves also producers. ${ }^{12}$ Conventionally bred Green Revolution crops thus exhibit the fundamental tension described above, albeit through mechanisms of technological transformation that are bound to strike casual observers of agriculture as exceedingly obscure.

\section{From GMOs to Gene Editing}

From the perspective of agricultural scientists, their approach to modifying the underlying genetics of a crop has progressed incrementally over more than a century. Farmer trial and error was replaced by statistical methods that gave scientists more insight into the genetic basis for desirable traits (such as drought tolerance, lodging, or simply producing more usable food product per plant). Techniques for inducing spontaneous change in plant genetics through chemical or radiological stress were introduced in the 1940s, followed by cell cultures that allowed scientists to regenerate an entire plant from a leaf or root. Cell cultures also gave scientists the power to cross species lines, albeit in a limited fashion. By the 1970s, scientists could change a microbe's genetics by inserting small bits of DNA directly into the genome, theoretically obliterating all barriers crossing species lines. These techniques were adapted to plants and animals in the 1980s. Human and veterinary 
pharmaceutical products manufactured from genetically engineered microbes and field testing of modified crops were both well underway by 1990 .

Products of recombinant-DNA gene transfer and modification entered the scene on the heels of both the tomato harvester controversy and the widespread debate over the ethical impacts of the Green Revolution. As such, advocates of farm labor and smallholding farmers had good reason to be suspicious of their socioeconomic impact and skeptical of their alleged environmental benefits. Indeed, in a highly publicized 1985 report by Cornell University, economist Robert Kalter predicted that massive shifts in the ownership and operation of the U.S. dairy industry would follow the introduction of recombinant bovine somatotropin (rBST). ${ }^{13}$ rBST is a drug produced by a genetically engineered microbe. It extends the lactation of dairy cows, putatively increasing the per-cow efficiency of milk production. It would be difficult to overstate the extent of the controversy over rBST among agricultural insiders throughout the 1980s. It even sparked an unprecedented one-year moratorium on its commercial use, enacted by the U.S. Congress so that the socioeconomic, human, and animal health impacts could be further studied.

For present purposes, the rBST controversy was important for aligning small farmers and their advocates-which in the 1980s and 1990s included the emerging organic production sector-against gene technologies. Their opposition was grounded in the litany of ethical problems that had been associated with selective breeding. Advocates of genetic engineering were boasting that recombinant tools [see Box 1] would increase the speed at which new crop or animal genetics could enter the marketplace. However, from the perspective of people who could expect to be on the losing end of a technological treadmill, this just meant that they would have less time to adapt and less time to organize any form of resistance. ${ }^{14}$ Advocates for aligning the public sector in agricultural research with initiatives that were more sensitive to a technology's disproportional impacts on resourcechallenged farmers and agricultural laborers, many of whom were women or from historically marginalized and exploited ethnicities, were especially critical of the rapid embrace of gene transfer within universities and nonprofit research institutes. ${ }^{15}$ 


\section{Box 1: The Recombinant DNA Tool Kit}

Most people understand genetic engineering as the addition, deletion, or replacement of specific gene constructs in an organism's DNA. This is only possible because DNA has the biochemical capacity for recombination: the molecule is reconstructed during cell division and organismal reproduction. In sexual reproduction, the new DNA molecule incorporates genes from both parents through recombination, producing a new and genetically unique molecule that becomes the basis for biological development of the progeny. Recombinant DNA refers to human manipulation of this biochemistry under laboratory conditions.

The GMO (genetically modified organism) is created by inserting genes into embryonic cells, in the case of animals, or into cells that will be reconstituted using cell culture, in the case of plants. These reconstituted plants will eventually produce seeds bearing the new genetic trait. This creates a new line or breed of organism in which progeny carry the genetic change in a heritable manner. For all of these tools, the genetic engineer has no control over where the novel genetic material is incorporated into the plant or animal genome. This creates the possibility that the insertion will disrupt the normal functioning of the organism. As such, first-generation genetic engineering was followed by additional rounds of conventional breeding, both to certify proper functioning and to ensure that the new genetic material was incorporated along with other traits (yield, lodging, and so on) of value to farmers.

Gene editing refers to a suite of new methods that allow insertions to be targeted to specific locations on the DNA molecule. However, agricultural scientists must still rely on the old suite of tools for getting genes into a plant or animal cell nucleus, and they still use cell culture to reconstitute plants capable of producing seed. These processes themselves place stress on organisms, which can cause spontaneous changes in DNA (though at a much lower rate than the random insertion of first-generation GMOs). There is thus a debate as to whether the increased precision in targeting the location of a genetic medication along the DNA molecule reflects a significant enough change to relax some of the post-insertion steps to ensure functionality, as well as the concomitant regulatory review. 
Advocates of increasing the pace at which plant and animal genetics could be manipulated in conjunction with other farming techniques would point to the Green Revolution with moral approval. After all, these technologies played a key role in defeating calamitous predictions of famine that were part of a concern in the 1960 s and 1970 over the rapidly increasing global population (this part of the story was largely left out by the advocates for smallholders). Influential books such as The Population Bomb and Famine 1975! predicted a sharp uptick in the global death rate and political upheavals tied to food shortages, but by 1990, it was clear that shortages had yet to arrive. Careful studies by economists and famine specialists noted how Green Revolution crops had indeed harmed some smallholders and agricultural laborers, as well as introduced the industrialized world's pollution problems to rural areas in India and Southeast Asia. Nevertheless, they also credited these crops with forestalling the predicted emergence of catastrophic famines.

The pro-biotechnology groups also had considerable advantages over smallholders and their allies in the policy arena. Start-up companies and established corporations alike saw the potential for major profits in two products from the first generation of GMOs: herbicide-tolerant crops and insect-resistant crops. Both seemed likely to follow earlier examples of gene technology by first offering efficiencies to early adopting farmers and then coming to dominate farming as these efficiencies became baked into the price that all farmers received on commodity markets. What is more, patent laws allowed the developers of GMOs to increase both profits and power over farm-level decision-makers. In short, money was a major factor in the early adoption of first-generation GMOs. While an ethics analysis would not necessarily weigh in against opportunities for profit, the money at stake in the first generation of GMOs seemed to tilt an already skewed playing field even more sharply in favor of people who were already much better off than the smallholders and laborers who would be adversely affected.

Yet at this juncture in the debate-between 1997, when GMOs were first grown on a large scale, and roughly 2007-advocates of smallholders received an unexpected boon. Worldwide, consumers began expressing significant resistance to eating genetically engineered crops. A summary of research exploring the basis for this resistance would exceed the remit of the present essay. However, it is safe to say that while some consumers were becoming enrolled in a movement to support organic production, purchasing at farmers' markets or resisting 
corporate influence over the food system, a vanishingly small percentage of them could have appreciated the nuances of the technology treadmill, or understood why advocates for smallholders were leery of this new genetic technology. As with their support for organic food, food safety, nutritional benefit, and environmental impact were foremost in the minds of such consumers. Along with some political instabilities in the at-the-time still emergent European regulatory system, consumer fears mobilized a continent against GMOs. Advocates of smallholders were quick to pressure European supermarkets against stocking products made with genetically engineered corn, soy, or rice. This strategy had a significant impact on African producers. Many African smallholders who we might think of as subsistence farmers in fact grow cash crops destined for European markets. If those markets disappear, so does the small farmer's cash income.

But what to make of all this from an ethics perspective? While the argument for protecting consumer preferences is strong, the case for questioning the safety of GMOs is weak. Dozens of scientific studies have concluded that crops or animals produced using recombinant tools are just as safe as those produced using selective breeding. ${ }^{16}$ Anti-biotechnology activists could make persuasive ethical arguments based on the history of gene technologies including selective breeding, but by instead appealing to the public's concern for the safety of GMOs specifically, they have been forced to soft-pedal these arguments. From a practical perspective, opposing GMOs means continuing to rely on the succession of conventionally bred varieties disseminated throughout the twentieth century, but this only reinforces a naïve presumption that this history is ethically unproblematic. What is more, the fundamental ethical tension between supporting producers and feeding consumers poses further motivational challenges for engaging the public. The treadmill argument asks us to see how feeding hungry people can have unwanted and unjust impacts on farmers. It thus complicates the intuition that has motivated a century of progress in recognizing the universal human right to food. To make matters even worse, the advocates of GMOs (and now gene-edited crops) can appeal directly to the naïve presumption that hunger will be overcome by expanding the supply of globally available food, while their opponents must make complicated arguments that an audience far removed from agriculture will be unlikely to appreciate.

In truth, even this summary vastly understates the ethical complexity of the issues. It does not engage questions about the environmental impact of GMOs, the rationale for segregating and labeling products of genetic engineering, or 
the role that patents play in increasing the power of companies selling seeds and chemical inputs to farmers. It has not mentioned how altering genetics can cause dysfunctionality and suffering in modified food animals, and has not even mentioned conventionally cited philosophical problems with the very idea of interference in the processes of heritability and evolution. ${ }^{17}$ The preceding analysis does not explain why the United States and Europe took different approaches to the regulation of GMOs, though the possibility that the European Union was more inclined to take these ethical issues seriously is a plausible hypothesis. ${ }^{18}$ Further elaboration would exceed the remit of the current essay.

\section{Conclusion: Whither Gene Technology?}

There is an ethical case for viewing any technology that increases the efficiency of farming with a certain amount of moral skepticism. GMOs and the next generation of genetically modified crops produced through more precise methods of genetic engineering are no exception. Past introductions have indeed led to increases in the availability of food, and corresponding reductions in the cost to consumers. However, every time the speed of the treadmill increases, there have been losers, and the losers have typically been precisely those who were already disadvantaged by economic deprivation, not to mention racial or gender bias and other imbalances of power and influence in the food system. At the same time, I would not want to be the person who stands between poor farmers and the ability to use seeds that will ease their burdens by resisting plant diseases or reducing the danger and drudgery of their work. New crop varieties might help poor farmers fare better in a changing climate or allow them to achieve a better return on their labor in a global commodity market. I would like to ally with smallholders and those who are calling for greater sovereignty over the food system, but I would like to do so by encouraging policy mechanisms that protect their interests without also discriminating unduly against a particular class of technologies that are no worse (if, indeed, no better) than all the rest.

The forces aligned against this middle course may be too powerful to overcome, however. Above all, there is the ethically crucial responsibility that all of us share in meeting the immediate food needs of a hungry person. It is difficult enough to remind the average person about or shock him or her into recognizing this noncontroversial duty. Those who promise to attack hunger, either through gifts of charity or through increasing yields, present us with an almost irresistible 
psychological appeal. My claim is that this appeal should be rechanneled, rather than opposed, on moral grounds. However, redirecting our fundamentally sound impulse to make sure that hungry people can eat requires us to understand how a clumsy and unsophisticated means to this end can cause hunger and injustice among equally poor and marginalized people in rural areas. Achieving this level of understanding may create intellectual burdens that very few of us are willing to bear. In opposing GMOs, advocates of poor smallholders stumbled onto a cause that, at a minimum, caused consternation among the boosters of gene technology, and that held out some limited promise of holding their feet to the fire. Resistance to GMOs may have been predicated on the hope that these technology promoters could be forced to provide their tools under conditions that would be more beneficial to smallholders.

If I had seen evidence that opposing GMOs or the next generation of gene technologies could force governments, corporate actors, and the agricultural research establishment into more ethically justifiable arrangements for introducing new technologies, I would be more sanguine about joining the protesters today. In fact, opposition to gene technology has taken on a life of its own and provided little benefit to anyone, save for those who profit from anti-GMO campaigns through fundraisers, speaking engagements, and book sales, or academics whose critical publications count as scholarly productivity in their annual reviews. It would be both false and churlish to accuse them of self-serving motives, for it is clear that most are sincere. Nevertheless, whatever lift anti-GMO activism may have given to the cause of the poor in the 1990s, the campaign has dissipated into one that, as Robert Paarlberg argues, keeps smallholders from having access to gene technologies that they would actually benefit from using. ${ }^{19}$

Yet I do not go so far as to endorse the world-feeding arguments of the science boosters, either. Climate change and population growth will challenge agricultural production systems of the future, especially given the virtual certainty that the most vulnerable producers will bear the brunt of rising sea levels and increased climatic variability. I do not doubt the need for agricultural science in meeting these challenges, nor do I dispute the role that gene technology can play. Nevertheless, the case being made in favor of gene technology is entirely too abstract to win moral endorsement. It is being argued totally in terms of global food needs, with no attention to the way that new technologies have had disproportionately harmful impacts on the people least able to cope with them. Until the case for biotechnology is coupled with new ideas for protecting the interests of 
women, disempowered minorities, and other smallholders, the confidence exuded by boosters will continue to be a source of skepticism for me, rather than assurance.

My conclusion, then, is pessimistic. The message about the ethics of agricultural and food biotechnology to which I dedicated my career of scholarship has been drowned out by simplistic boosterism, on one side, and a blend of fearmongering and ignorance of food systems, on the other. The details that matter are obscured by the current debate, and require a cognitive effort that few observers, including many ethicists, are willing to expend. I do not hold out much hope that this will change, but I continue my appeal to scholars in ethics, and especially to those who take an interest in ethics and international affairs.

\section{NOTES}

${ }^{1}$ For a recent treatment of the subject, see Timothy A. Wise, Eating Tomorrow: Agribusiness, Family Farmers, and the Battle for the Future of Food (New York: New Press, 2019).

2 Alan L. Olmstead and Paul W. Rhode, "Beyond the Threshold: An Analysis of the Characteristics and Behavior of Early Reaper Adopters," Journal of Economic History 55, no. 1 (March 1985), pp. 27-57.

${ }^{3}$ Willard Wesley Cochrane, The Development of American Agriculture: A Historical Analysis (Minneapolis: University of Minnesota Press, 1979).

${ }^{4}$ Harry C. Dillingham and David F. Sly, "The Mechanical Cotton-Picker, Negro Migration, and the Integration Movement," Human Organization 25, no. 4 (Winter 1966), pp. 344-51.

${ }^{5}$ Bill Winders, The Politics of Food Supply: U.S. Agricultural Policy in the World Economy (New Haven, Conn.: Yale University Press, 2009).

${ }^{6}$ Andrew Schmitz and David Seckler, "Mechanized Agriculture and Social Welfare: The Case of the Tomato Harvester," American Journal of Agricultural Economics 52, no. 4 (November 1970), pp. 569-77.

7 Robert D. Emerson, “Agricultural Labor Markets and Immigration,” Choices 22, no. 1 (2007), pp. 57-66.

8 Jim Hightower, Hard Tomatoes, Hard Times (Cambridge, Mass.: Schenkman, 1973).

9 M. S. Swaminathan, "Norman E. Borlaug (1914-2009)," Nature 46 (October 14, 2009), p. 894.

${ }^{10}$ Harry M. Cleaver Jr., "The Contradictions of the Green Revolution," American Economic Review 62, no. 1/2 (March 1, 1972), pp. 177-86.

${ }^{11}$ Vernon W. Ruttan, "Controversy about Agricultural Technology Lessons from the Green Revolution," International Journal of Biotechnology 6 (2004), pp. 43-54.

${ }^{12}$ Michael Lipton with Richard Longhurst, New Seeds and Poor People (Baltimore: Johns Hopkins University Press, 1989).

${ }^{13}$ Robert J. Kalter, "The New Biotech Agriculture: Unforeseen Economic Consequences," Issues in Science and Technology 2, no. 1 (Fall 1985), pp. 125-33.

${ }^{14}$ Frederick H. Buttel, "Ever Since Hightower: The Politics of Agricultural Research Activism in the Molecular Age," Agriculture and Human Values 22, no. 3 (September 2005), pp. 275-83.

15 Rebecca Goldburg, Jane Rissler, Hope Shand, and Charles Hassebrook, Biotechnology's Bitter Harvest: Herbicide-Tolerant Crops and the Threat to Sustainable Agriculture: A Report of the Biotechnology Working Group (Washington, D.C.: Biotechnology Working Group, March 1990).

${ }^{16}$ Harry A. Kuiper, Gijs A. Kleter, Hub P. J. M. Noteborn, and Esther J. Kok, "Assessment of the Food Safety Issues Related to Genetically Modified Foods," Plant Journal 27 (December 2001), pp. 503-28; and Alessandro Nicolia, Alberto Manzo, Fabio Veronesi, and Daniele Rosellini, "An Overview of The Last 10 Years of Genetically Engineered Crop Safety Research," Critical Reviews in Biotechnology 34, no. 1 (September 2013), pp. 77-88.

17 For a discussion of all of these issues, see Paul B. Thompson, Food and Agricultural Biotechnology in Ethical Perspective, 3rd ed. (New York: Springer, 2020).

18 Bjørn Kåre Myskja and Anne Ingeborg Myhr, "Non-Safety Assessments of Genome-Edited Organisms: Should They Be Included in Regulation?," Science and Engineering Ethics 26, no. 5 (October 2020), pp. 2601-27. 
19 Robert L. Paarlberg, Starved for Science: How Biotechnology Is Being Kept Out of Africa (Cambridge, Mass.: Harvard University Press, 2009).

Abstract: The global food system exhibits dizzying complexity, with interaction among social, economic, biological, and technological factors. Opposition to the first generation of plants and animals transformed through rDNA-enabled gene transfer (so-called GMOs) has been a signature episode in resistance to the forces of industrialization and globalization in the food system. Yet agricultural scientists continue to tout gene technology as an essential component in meeting future global food needs. An ethical analysis of the debate over gene technologies reveals the details that matter. On the one hand, alternative regimes for institutionalizing gene technology (through regulation, trade policy, and intellectual property law) could mitigate injustices suffered by politically marginalized and economically disadvantaged actors in the food system, especially smallholding farmers in less industrialized economies. On the other hand, GMO opposition has been singularly effective in mobilizing citizens of affluent countries against policies and practices that lie at the heart of these same injustices. As part of the roundtable, "Ethics and the Future of the Global Food System," this essay argues that charting a middle course that realizes the benefits of gene technology while blocking its use in the perpetration of unjust harms may require a more detailed grasp of intricacies in the food system than even motivated bystanders are willing to develop.

Keywords: agricultural development, agricultural science, applied ethics, biotechnology, distributive justice, farming, food systems, gene editing, GMOs, philosophy of technology 